\title{
The impact of international energy price on Romanian macroeconomic
}

Yukun, XIAO, Ocean university of China, Qingdao, China 447544146@qq.com

\begin{abstract}
The recent decade has witnessed wild swings in International Energy price, and there is no doubt that a large fluctuation in energy prices will have an impact on a country's macro economy. This study examines the impact of international energy price on Romanian macroeconomic - $\mathrm{CPI}$, exchange rate and industrial product - by using Granger causality test and quantiles regression. We find that the international energy price can affect the CPI and industrial product of Romania, while it can't influence exchange rate at all. Also when energy price increase and decrease, it will have different impact on Romanian macroeconomic.

Keywords: International energy price; Romanian macroeconomic; Granger causality test; quantiles regression
\end{abstract}

JEL Classification: E2, E3, E6.

\section{Introduction}

With economic development, Romania's demand for energy is growing. Romania is working to develop renewable energy, and according to the Commission report released in 2016, Romania's energy self-sufficiency rate ranked third in the EU, but at this stage Romania still has part of the energy needs to import. According to World Bank statistics, Romania's average energy import rate for the 22 years (1990-2012) was $26.46 \%$, although the overall trend has decreased, in 2016, Romania's energy import rate reached $17 \%$. Therefore, the fluctuation of international energy prices will still have impact on Romania's economy. 
A large number of scholars have studied the relationship between energy prices and the economy. Previous studies fall into two groups: those that focus primarily on the volatility between energy price and the whole macroeconomic (often represent by stock market or country's GDP). Among those that have analyzed the whole macroeconomic, Mignon (2006) use OLS method, found that there exist asymmetric cointegration between oil price and France, Germany and other European countries. Van der Ploeg and Poelhekke (2009), note, both oil and non-oil price volatility reduces economic growth and helps contribute to the so-called "resource curse". Mohamed El Hedi Arouri, Jamel Jouini and Duc Khuong Nguyen (2012) applied VAR-GARCH model to study the impacts of oil price fluctuations on European equity markets. They found that oil price can signifivant affect sector stock returns in Europe. Rania Jammazi (2012) choose five developed countries (USA, UK, Japan, Germany and Canada), to investigate the volatility spillovers between oil price and stock market returns. By using wavelet-multivariate Markov switching GARCH model, they found that the connections between the joint equity and crude oil high volatility state and international recessions is fairly close. Aymen Belgacem (2015) applied an event study methodology to investigate the macroeconomic announcements effects on Standard \& Poor's 500 and oil prices in US. They found that oil prices and exchange rates are independent during the pre-crisis period. However, there's a positive dependence between those two variables after the crisis onset.

In the second group, exchange rates are treated as the most important macroeconomic variable, followed by CPI and other macroeconomic variable. Juncal Cuñado and Fernando Pérez de Gracia (2003) select inflation and industrial production indexes as a measure of macroeconomic indicators, have study the relationship between oil price and macroeconomy. They found that the volatility of oil prices had an impact on the macroeconomy. Sandrine Lardica and Vale' rie Pantelis Capros (2016) examine the macroeconomic and sectoral effects of energy prices in EU. The results also show that there's connection between the macroeconomic and energy price. Nikanor I. Volkov and Ky-hyang Yuhn (2016) use GARCH to investigates the effects of oil price shocks on exchange rate movements in five major oil-exporting countries: Russia, Brazil, 
Mexico, Canada, and Norway. They found that the volatility of exchange rates associated with oil price shocks is significant in Russia, Brazil, and Mexico, but weak in Norway and Canada. Vitaly Pershin (2016) investigates the relationship between oil prices and exchange rates in three African countries using a VAR model. Scott W. Hegerty (2016) applied VAR-MGARCH model to examine commodity-price volatility and macroeconomic spillovers in nine emerging country. The study choose five macroeconomics variables (exchange rate, interest rate, output, inflation and commodity price), and the result shows that Russia is found to be highly insulated from fluctuations in world oil prices. Muntazir Hussain (2017) applied a detrended cross-correlation approach (DCCA) to investigate the co-movements of the oil price and exchange rate in 12 Asian countries. The result shows that there's a weak negative cross-correlation between oil price and exchange rate for most Asian countries. Claudio Morana (2017) applied SP-DCC model to investigate the macroeconomic and financial effects of oil price shocks for the euro area.

This paper's contribution to the literature is twofold. First, from a new perspective - the impact of international energy prices on Romania's macroeconomy - to test a possible reason for the effect of Romania's macro economy. Second, after apply Granger causality test to those two variables, this paper use quantile regression to examine this impact from a more complete and global vision.

\section{Methodology}

Using monthly data from the International Monetary Fund, we first test the Granger causality relationship between international energy price and three macroeconomic variables - CPI, exchange rate and industry product.

The Granger causality test was created by Clive W. J. Granger. As presented by Pantelis \& co.[13] let considering $y$ and $x$ be stationary time series. To test the null hypothesis that $x$ does not Granger-cause $y$, one first finds the proper lagged values of $y$ to include in a univariate autoregression of $y$ :

$$
y_{t}=a_{0}+a_{1} y_{t-1}+a_{2} y_{t-2}+\cdots+a_{m} y_{t-m}+\text { error }
$$

Next, the autoregression is augmented by including lagged values of $x$ : 


$$
y_{t}=a_{0}+a_{1} y_{t-1}+a_{2} y_{t-2}+\cdots+a_{m} y_{t-m}+b_{p} x_{t-p}+\cdots+b_{q} x_{t-q}+\text { error }
$$

One retains in this regression all lagged values of $x$ that are individually significant according to their t-statistics, provided that collectively they add explanatory power to the regression according to an F-test. In the notation of the above augmented regression, $p$ is the shortest, and $q$ is the longest, lag length for which the lagged value of $x$ is significant.

The null hypothesis that $x$ does not Granger-cause $y$ is not rejected if and only if no lagged values of $x$ are retained in the regression.

After testing for Granger causality, we estimate the quantile regression to further explore the volatility spillover effect between the energy market and the Romanian macroeconomic.

A major theorem about quantile regression was proposed in 1760 by Ruđer Josip Bošković., until the widespread adoption of computers in the latter part of the 20th century; it is presented by Schancez-Vidal [17]

A quantile regression provides a more complete vision of how diverse factors affect the various quantiles differently in terms of the variables of macroeconomic conditional distribution. OLS estimators show the impact of these factors over the conditional mean of the variables of macroeconomic. Usually, this is expressed by the following linear model:

$$
Y=X \beta+u
$$

Econometricians have been increasingly aware that the traditional linear model with i.i.d errors may not be the best way to treat models such as Eq. (3). In this model $X$ is assumed to affect the $Y$ conditional distribution, but not its scale. If this is the case and the aim of the model is to provide a complete characterization of the $Y$ conditional distribution on $X$, the appropriate thing to do would be to use other non-mean-based measures. Generally, one can formulate the following model for the $\tau$-th quantile of $Y$ :

$$
Q_{\tau}=X \beta(\tau)
$$

Where the orthogonality condition of $u$ is assumed for the $\tau$-th quantile. This estimation procedure gives a series of quantile regression functions, one for 
each $\tau$, which provides a more complete and global vision of the $X$ and $Y$ relationship. In addition, if $\tau=0.5$ this will be a traditional OLS regression.

\section{Empirical results and analysis}

Fig. 1 shows the movement of international energy price and macroeconomic variables, from January 1991 to March 2017. This paper chooses $\mathrm{CPI}$, exchange rate and industrial product as variables of Romanian macroeconomics. We see large increases, such as for energy price in the begin 2008 and 2011, as well as decreases (such as for energy price in the 2009). Compared with the price of energy, the fluctuation of macroeconomic variables is relatively stable.

Table 1 provides the descriptive statistics for energy price and variables of macroeconomic- in month-on-month log changes. We can see from table 1 that all the data we need is smooth. Energy price, $\mathrm{CPI}$ and exchange rate have left deviation degree. Industrial product has right deviation degree.

Table 2 shows the Grainger causality test results. The order for the test is found by conducting it at 10 lags. From the lag two, energy prices have a significant impact on the CPI. However, energy prices have a significant impact on industrial production in the lag three to five, and then, energy price will have no significant effect on industrial production. As for exchange rate, from our empirical results, energy prices have no impact on it at all. 
energy price

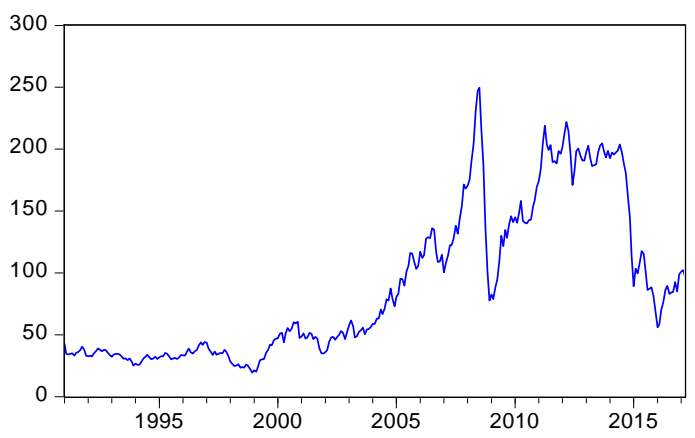

exchange rate

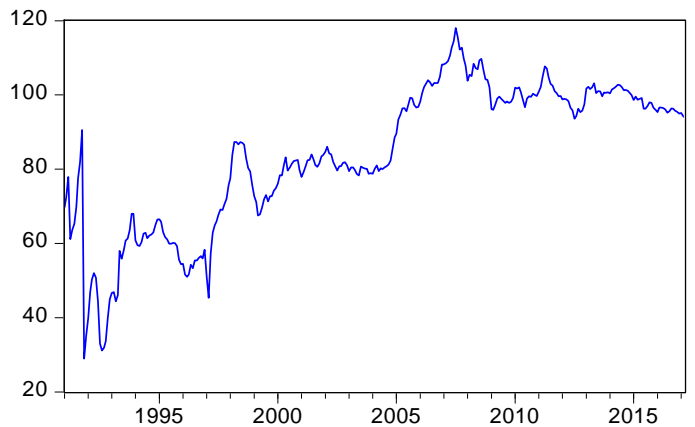

CPI

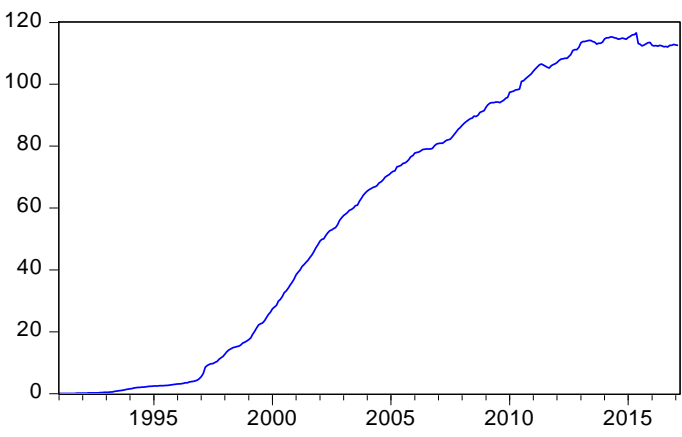

industrial production

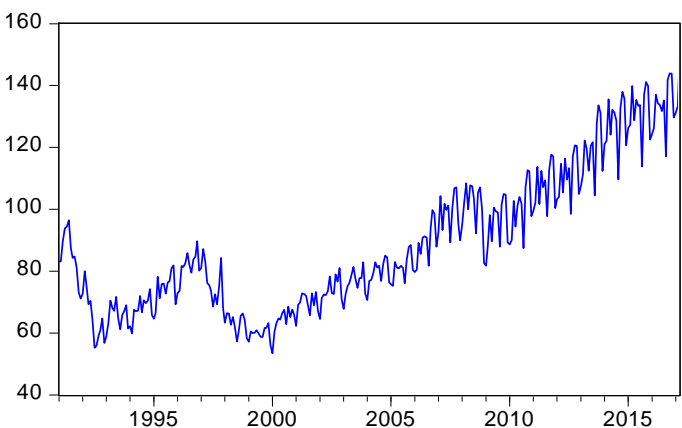

Fig.1 Index chart

Table1 Descriptive statistics and test values

\begin{tabular}{lllll}
\hline & $\Delta$ Energy Price & $\Delta \mathrm{CPI}$ & $\begin{array}{l}\Delta \text { Exchange } \\
\text { Rate }\end{array}$ & $\begin{array}{l}\Delta \text { Industrial } \\
\text { Product }\end{array}$ \\
\hline Mean & 0.169233 & 0.358735 & 0.076828 & 0.216360 \\
Median & 0.716557 & 0.293398 & 0.149498 & 0.594876 \\
Maximum & 26.28388 & 2.533928 & 11.96010 & 24.69383 \\
Minimum & -50.72512 & -3.437899 & -61.53331 & -19.79505 \\
Std. Dev. & 8.350498 & 0.477434 & 4.323025 & 7.289548 \\
Skewness & -1.511090 & -0.895895 & -9.320022 & 0.001211 \\
Kurtosis & 9.860615 & 16.19380 & 133.7938 & 4.199814 \\
Jarque-Bera & $735.3045^{* * *}$ & $2319.503^{* * *}$ & $228362.8 * * *$ & $18.83423^{* * *}$ \\
ADF Test & $-11.24634 * * *$ & $-7.279371 * * *$ & $-18.82160 * * *$ & $-3.780673 * * *$ \\
\hline
\end{tabular}

$*, * *$ and $* * *$ indicate the rejection of the null hypothesis, normality and homoscedasticity at the $10 \%, 5 \%$ and $1 \%$ levels of significance respectively.

Table 3 shows the results for the quantile regressions at the $0.10,0.30,0.50$, 0.70 and 0.90 quantiles with 2 lag, which provides a more complete and global vision of the impact of international energy price to Romanian macroeconomic. 
At the $0.10,0.30,0.50$ quantiles, international energy price have a significant impact on CPI in the current period. And at the 0.30, 0.50, 0.70 quantiles, international energy price have a significant impact on CPI after two lag. It means when energy price decrease, it will affect the CPI immediately, and this effect has a lasting effect. However, when energy price increase, it can't affect CPI at current period, energy prices will have an impact on CPI after two lag. As for industrial product, at the 0.90 quantile, the energy price have significant impact on it. So we can conclude that only when international energy price increase rapidly it will affect industrial product immediately.

Table 2 Grainger causality test results

\begin{tabular}{|c|c|c|c|c|c|}
\hline \multicolumn{2}{|c|}{ Energy price $\neq>\mathrm{CPI}$} & \multicolumn{2}{|c|}{$\begin{array}{l}\text { Energy price } \neq> \\
\text { Exchange rate }\end{array}$} & \multicolumn{2}{|c|}{$\begin{array}{l}\text { Energy } \\
\text { production }\end{array}$} \\
\hline Lag & F-value & Lag & F-value & Lag & F-value \\
\hline 1 & 0.22088 & 1 & 0.42888 & 1 & 1.27308 \\
\hline 2 & $3.54563 * *$ & 2 & 0.34437 & 2 & 1.46048 \\
\hline 3 & $2.79225^{* *}$ & 3 & 0.28568 & 3 & $2.82786 * *$ \\
\hline 4 & 2.17924* & 4 & 0.28264 & 4 & $2.10306 *$ \\
\hline 5 & $4.14386 * * *$ & 5 & 0.42763 & 5 & $2.05349 *$ \\
\hline 6 & $3.87892 * * *$ & 6 & 0.44035 & 6 & 1.77657 \\
\hline 7 & $3.22229 * * *$ & 7 & 0.43124 & 7 & 1.53853 \\
\hline 8 & $3.21666 * * *$ & 8 & 0.39989 & 8 & 1.52550 \\
\hline 9 & $2.84809 * * *$ & 9 & 0.45581 & 9 & $1.91939 * *$ \\
\hline 10 & $2.25468 * *$ & 10 & 0.80597 & 10 & 1.37404 \\
\hline
\end{tabular}

Table 3 Quantile regression results

\begin{tabular}{|c|c|c|c|c|c|c|c|}
\hline \multicolumn{4}{|c|}{ Energy price - CPI } & \multicolumn{4}{|c|}{ Energy price - Industrial product } \\
\hline Quantile & Energy & $\begin{array}{l}\text { Energy(- } \\
\text { 1) }\end{array}$ & $\begin{array}{l}\text { Energy(- } \\
\text { 2) }\end{array}$ & Quantile & Energy & $\begin{array}{l}\text { Energy(- } \\
\text { 1) }\end{array}$ & $\begin{array}{l}\text { Energy(- } \\
\text { 2) }\end{array}$ \\
\hline 0.1 & $\begin{array}{l}0.00823 \\
{[2.01565]} \\
(0.0447)\end{array}$ & $\begin{array}{l}0.00489 \\
{[1.14112]} \\
(0.2547)\end{array}$ & $\begin{array}{l}-0.00599 \\
{[-} \\
1.36010] \\
(0.1748)\end{array}$ & 0.1 & $\begin{array}{l}0.08539 \\
{[0.96412]} \\
(0.3357)\end{array}$ & $\begin{array}{l}0.07999 \\
{[0.41391]} \\
(0.3357)\end{array}$ & $\begin{array}{l}0.06106 \\
{[0.52841]} \\
(0.5976)\end{array}$ \\
\hline 0.3 & $\begin{array}{l}0.00854 \\
{[2.39491]} \\
(0.0172)\end{array}$ & $\begin{array}{l}0.00481 \\
{[1.21705]} \\
(0.2245)\end{array}$ & $\begin{array}{l}-0.00895 \\
{[-} \\
2.82519] \\
(0.0050)\end{array}$ & 0.3 & $\begin{array}{l}0.07494 \\
{[0.79494]} \\
(0.4273)\end{array}$ & $\begin{array}{l}0.07942 \\
{[0.98057]} \\
(0.3276)\end{array}$ & $\begin{array}{l}-0.07436 \\
{[-} \\
0.80715] \\
(0.4202)\end{array}$ \\
\hline
\end{tabular}


HOLISTICA Vol 8, Issue 2, 2017

\begin{tabular}{|c|c|c|c|c|c|c|c|}
\hline 0.5 & $\begin{array}{l}0.00865 \\
{[2.84478]} \\
(0.0047)\end{array}$ & $\begin{array}{l}0.00495 \\
{[1.19897]} \\
(0.2315)\end{array}$ & $\begin{array}{l}-0.00560 \\
{[-} \\
1.67089] \\
(0.0958)\end{array}$ & 0.5 & $\begin{array}{l}0.01569 \\
{[0.24317]} \\
(0.8080)\end{array}$ & $\begin{array}{l}-0.05256 \\
{[-} \\
0.71305] \\
(0.4764)\end{array}$ & $\begin{array}{l}0.03191 \\
{[0.45418]} \\
(0.6500)\end{array}$ \\
\hline 0.7 & $\begin{array}{l}0.00375 \\
{[0.70974]} \\
(0.4784)\end{array}$ & $\begin{array}{l}0.00484 \\
{[1.06989]} \\
(0.2855)\end{array}$ & $\begin{array}{l}-0.00917 \\
{[-} \\
1.71156] \\
(0.0880)\end{array}$ & 0.7 & $\begin{array}{l}-0.05679 \\
{[-0.74816]} \\
(0.4549)\end{array}$ & $\begin{array}{l}0.03801 \\
{[0.43317]} \\
(0.6652)\end{array}$ & $\begin{array}{l}0.01643 \\
{[0.25066]} \\
(0.8022)\end{array}$ \\
\hline 0.9 & $\begin{array}{l}-0.00692 \\
{[-0.71463]} \\
(0.4754)\end{array}$ & $\begin{array}{l}-0.00529 \\
{[-} \\
0.61829] \\
(0.5368)\end{array}$ & $\begin{array}{l}0.00098 \\
{[0.19840]} \\
(0.8429)\end{array}$ & 0.9 & $\begin{array}{l}-0.10127 \\
{[-1.72104]} \\
(0.0862)\end{array}$ & $\begin{array}{l}0.06827 \\
{[0.84276]} \\
(0.4000)\end{array}$ & $\begin{array}{l}0.08859 \\
{[1.23243]} \\
(0.2187)\end{array}$ \\
\hline
\end{tabular}

T statistics in the Square brackets, $p$ values in the parentheses.

\section{Conclusion}

This paper mainly tests the impact of international energy price on Romanian macroeconomics by using Grainger causality test and quantile regression. The results show that international energy price can affect $\mathrm{CPI}$ and industrial product of Romania, but it doesn't work when refer to exchange rate. More specifically, energy price have significant impact on CPI in low quantile at current period and in high quantile after two lag, which means when energy price decrease, it will affect CPI immediately in a relatively long period of time, and when energy price increase, it will affect industrial product after almost two month. Similarly, when energy price increase rapidly, it will affect the industrial product.

From this paper we can see that for the energy utilization, Romania has done well. Meanwhile, although Romania has largely achieved energy independence, international energy price still can influence the macroeconomic of Romania. I think it is still necessary for Romania to further increase investment in new energy development and utilization. 


\section{References}

[1] Hiro Y. Toda, Taku Yamamoto. Statistical inference in vector autoregressions with possibly integrated processes[J]. Journal of Econometrics, 1995, 66(1): 225-250

[2] Juncal Cuñado, Fernando Pérez de Gracia. Do oil price shocks matter? : Evidence for some European countries[J]. Energy Economics, 2003, 25(2): 137-154

[3] Sandrine Lardic, Vale'rie Mignon. The impact of oil prices on GDP in European countries: An empirical investigation based on asymmetric cointegration[J]. Energy Policy, 2006, (34): 3910-3915

[4] Frederick van der Ploeg, Steven Poelhekke. Volatility and the natural resource curse[J]. Oxford Economic Papers, 2009, (61): 727-760

[5] Rania Jammazi. Oil shock transmission to stock market returns: Wavelet-multivariate Markov switching GARCH approach[J]. Energy, 2012, (37): 430-454

[6] Mohamed El Hedi Arouri, Jamel Jouini, Jamel Jouini. On the impacts of oil price fluctuations on European equity markets: Volatility spillover and hedging effectiveness[J]. Energy Economics, 2012, (34): 611-617

[7] F. Javier Sánchez-Vidal. High debt companies' leverage determinants in Spain: A quantile regression approach[J]. Economic Modelling, 2014, (36): 455-465

[8] Christiane Baumeister, Lutz Kilian. Do oil price increases cause higher food prices[J]. Econ Policy , 2014, 80(29): 691-747

[9] Aymen Belgacem, Anna Creti, Khaled Guesmi \& Amine Lahiani. Volatility spillovers and macroeconomic announcements: evidence from crude oil markets[J]. Applied Economics , 2015, (13): 2974-2984

[10] Nikanor I. Volkov, Ky-hyang Yuhn. Oil price shocks and exchange rate movements[J]. Global Finance Journal, 2016, (31): 18-30

[11] Angham Ben Brayek, Saber Sebai, Kamel Naoui. A study of the interactive relationship between oil price and exchange rate: A copula approach and a DCC-MGARCH model[J]. The Journal of Economic Asymmetries, 2015, (12): 173-189

[12] Vitaly Pershin, Juan Carlos Molero, Fernando Perez de Gracia. Exploring the oil prices and exchange rates nexus in some African economies[J]. ScienceDirect, 2016, (38): 166-180

[13] Pantelis Capros, Leonidas Paroussos, Ioannis Charalampidis and Kostas Fragkiadakis, Panagiotis, Karkatsoulis, Stella, Tsani. Assessment of the macroeconomic and sectoral effects of higher electricity and gas prices in the EU: A general equilibrium modeling approach[J]. Energy Strategy Reviews, 2016, (9): 18-27

[14] Scott W. Hegerty. Commodity-price volatility and macroeconomic spillovers: Evidence from nine emerging markets[J]. North American Journal of Economics and Finance, 2016, (35): 23-27

[15] Muntazir Hussain, Gilney Figueira Zebende, Usman,Bashir, Ding Donghong. Oil price and exchange rate co-movements in Asian countries: Detrended cross-correlation approach[J]. Physica A, 2017, (465): 338-346

[16] Claudio Morana. Macroeconomic and financial effects of oil price shocks: Evidence for the euro area[J]. Economic Modelling, 2017, (64): 82-96

[17] Sánchez-Vidal , F. Javier . " High debt companies' lever age determinants in Spain: A quantile regression approach" , Economic Modelling, Volume 36, January 2014, Pages 455-465 